\title{
Knowledge Level Analysis of Community stigma on ODP, PDP and COVID 19 Patients Through Attitude in Kediri District
}

\author{
Wahyu Sri Astutik, Reny Nugraheni* \\ Institut Ilmu Kesehatan Bhakti Wiyata, Indonesia \\ *reny.nugraheni@iik.ac.id
}

\begin{abstract}
Covid 19 is a virus that spreads rapidly through droplets of COVID 19 patients. Prevention of physical distancing is apparently not optimal enough in several countries including Indonesia. As proof, the number of Covid 19 patients continues to increase rapidly in various parts of Indonesia, including in the District of Kediri. One of the problems arising from Covid 19 is the occurrence of stigma in ODP, PDP, Covid 19 Patients, even in health professionals who can cause the failure of the Covid 19 prevention program. If not immediately find the cause of this stigma, and then the stunting prevention program will not run optimally. The purpose of the research is to determine the effect of knowledge on attitude, to know the effect of knowledge on stigma, to determine the effect of attitude on stigma and to determine the effect of knowledge on stigma through attitude. The population in this study was the people of Kediri Regency, and the sample in this study was random sampling and received a sample of 150 people. The results showed that knowledge influences attitude, knowledge influences stigma, attitude influences stigma and knowledge influences stigma through attitude.
\end{abstract}

Keywords: Knowledge, Attitude, Stigma 


\section{STRADA Jurnal Ilmiah Kesehatan}

DOI: $10.30994 /$ sjik.v9i2.486

ISSN: 2252-3847 (print); 2614-350X (online)

Vol.9 No.2 November 2020 Page.1457-1462

\section{BACKGROUND}

Covid 19 is a new virus that first appeared in Wuhan China in 2019, the corona virus can interfere with breathing, lungs, and even death in patients. Corona virus spreads very quickly to various countries in the world including Indonesia. According to the World Health Organization (WHO) Covid 19 is an infectious disease caused by the corona virus.

The initial symptoms of coronavirus sufferers are characterized by fever, runny nose, dry cough, sore throat and headache if within a few days do not heal instead have an increase in cough with phlegm and shortness of breath and chest pain should immediately be brought to pain because if it is too late it will result in Dead.

People suspected of being infected with the corona virus or so-called ODP (people in monitoring) or PDP (patients in monitoring) should be taken several steps so that they are not transmitted to other people who have not been infected, including; Doing independent isolation by means of people affected by the virus live separately with others for a while, contact the hospital if you want treatment, do not have meetings with other people, use tissue when coughing or sneezing so as not to transmit the virus to others.

Attitude is a person's closed response to a particular stimulus or object, which already involves the relevant opinion and emotion factors. Attitudes can be distinguished by their shape in a positive attitude and negative attitude. (Notoatmodjo, 2010) in this study the positive attitude in question is a caring attitude towards ODP, PDP and Covid patients 19. Negative attitude in this study is the attitude of not caring even mocking people who are currently in ODP, PDP, Covid 19 patients.

According to Bloom, knowledge is the result of what is known and obtained after people have sensed a certain object, in this study the pengutan related to the covid 19 virus which is seen from three elements: the cause is what causes people to contract the covid 19 virus, the spread is how the spread of covid 19. and impact that is how the impact of covid 19 virus.

\section{METHOD}

\section{Research Design}

This research is explanatory using quantitative descriptive analysis, using SEM analysis tools, aims to determine the relationship of knowledge and attitudes towards community stigma on ODP, PDP and Covid patients19 with calculations using the AMOS program.

\section{Definition of Operational variables}

a) Knowledge

Knowledge is the result of sensing the senses that are owned, as measured by indicators: causes, spread and impact.

b) Attitude

Attitude is a response to certain stimuli or actions that involve factors of opinion and emotion, as measured by indicators: positive and negative.

c) Stigma

Stigma is a form of assessment in the form of attributes that can reduce social identity, as measured by indicators: ODP, PDP, patients and health workers.

\section{Population and sample}

The population in this study was the people of Kediri districts and the sampling technique in this study was random sampling of 150 people. 


\section{STRADA Jurnal Ilmiah Kesehatan}

DOI: $10.30994 /$ sjik.v9i2.486

ISSN: 2252-3847 (print); 2614-350X (online)

Vol.9 No.2 November 2020 Page.1457-1462

\section{Data analysis techniques}

Data obtained from respondents' perceptions were then analyzed descriptively by structural equation modeling using the AMOS application.

\section{Analysis Results}

1. SEM Analysis Results

Based on literature studies and operational definitions the research variables produce the following model structure:

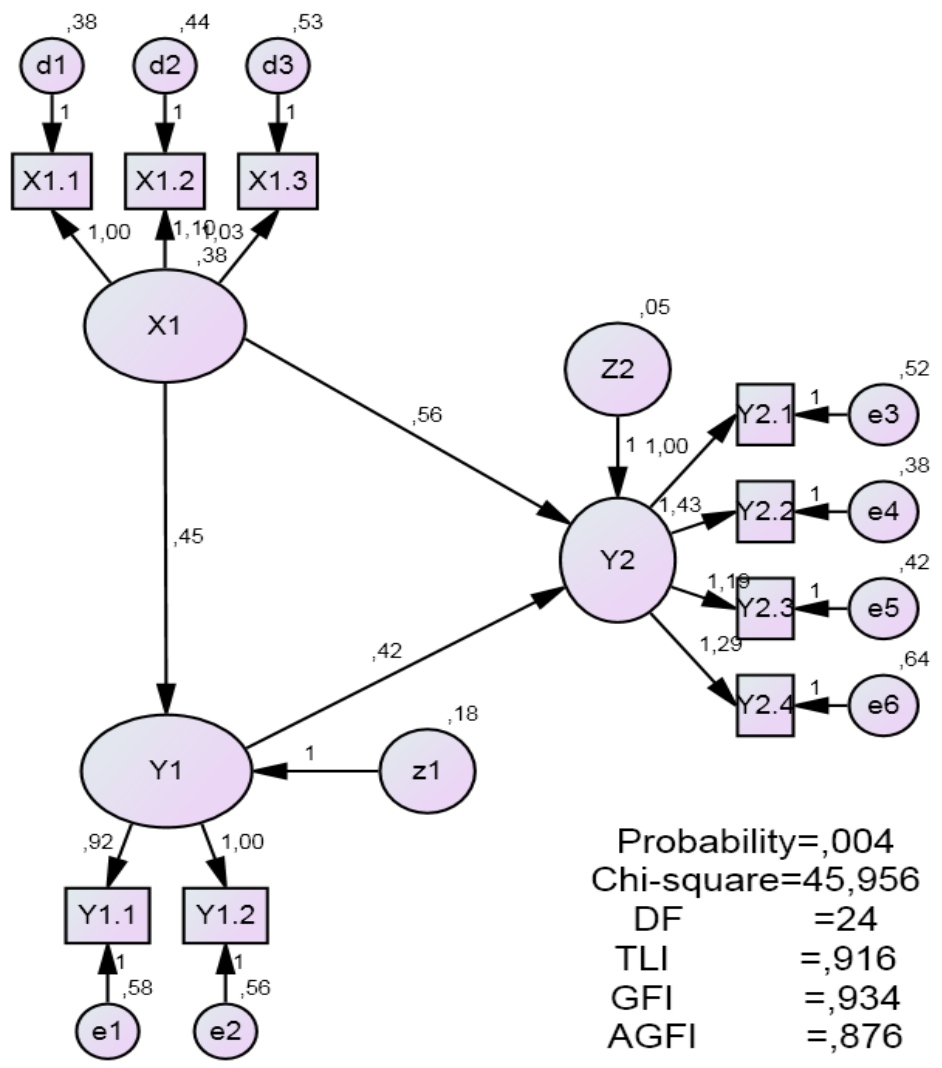

X1 Knowlegde

SEM Picture

$\mathrm{X} 1.1$ Cause

$\mathrm{x} 1.2$ Spread

$\mathrm{X} 1.3$ Impact

\section{X2 Sikap}

X1.1 Positive

$\mathrm{X} 1.2$ Negative

\section{Y1 Stigma}

Y1.1 ODP

Y1.2 PDP

Y1.3 Patient

Y1.4 Health workers 


\section{STRADA Jurnal Ilmiah Kesehatan}

DOI: $10.30994 /$ sjik.v9i2.486

ISSN: 2252-3847 (print); 2614-350X (online)

Vol.9 No.2 November 2020 Page.1457-1462

e1 = unobserved endogenous variable from the loading factor (endogenous latent variable)

$\mathrm{Y} 1$ and $\mathrm{Y} 2$

$\mathrm{d} 1$ = unobserved endogenous variable of a loading factor (endogenous latent variables) $\mathrm{X}$

$\mathrm{Z} 1=$ unobserved variable for latent endogenous variables

The results of the modeling equation structural analysis conducted with the help of computer program AMOS 16 for windows. Here it is known that all the criteria for Goodness of-fit indeces meet the requirements as shown in table 1.

Table 1 Goodness of-Fit Indeces Value and SEM cut-off value model

\begin{tabular}{llll}
\hline Criteria & Cut-off value & Model Test Results & Information \\
\hline Chi Square & Small Expected & 45.956 & Good \\
Sig. probability & $>0.05$ & 0.004 & Poorly \\
CMIN/DF & $\leq 2.00$ & 1.915 & Godd \\
RMSEA & $\leq 0.08$ & 0.078 & Good \\
TLI & $\geq 0.90$ & 0.916 & Good \\
GFI & $\geq 0.90$ & 0.934 & Good \\
\hline
\end{tabular}

Source: Primary data processed in 2020

Tabel 2 Uji Hipotesis

\begin{tabular}{llllllll}
\hline Hi & & & & & & & Prob \\
p. & Variable & & & Direct & Indirect & Total & \\
\hline $\mathrm{H}_{1}$ & Knowledge & Towards & Attitude & 0,447 & & 0,447 & 0.000 \\
$\mathrm{H}_{2}$ & Knowledge & Towards & Stigma & 0,558 & & 0,558 & 0.000 \\
$\mathrm{H}_{3}$ & Attitude & Towards & Stigma & 0,424 & & 0,424 & 0.029 \\
$\mathrm{H}_{4}$ & & Stigma through & & & & \\
\multicolumn{2}{c}{ Knowledge } & Towards & attitude & 0,558 & 0,187 & 0,745 & 0.000 \\
\hline \multicolumn{2}{c}{ At a significant level of 5\% } & & & &
\end{tabular}

\section{DISCUSSION}

\section{Effect of knowledge on attitude}

Based on the results of the study indicate that knowledge influences attitude. Knowledge that consists of the causes, spreads and impacts that are dominated by the spread reflected by the COVID-19 virus is spread through droplets (respiratory droplets) of people who have been infected and the COVID-19 virus spreads because interacting with many people influences the positive and negative attitudes dominated by negativity reflected in uncomfortable feelings when a neighbor becomes ODP COVID 19 and feels uncomfortable if a neighbor becomes PDP COVID 19. The results of this study are not in accordance with the results of a study conducted by Adekunbi, 2015, a research entitled "Knowledge, attitude, and practice of HIV/AIDSrelated stigma and discrimination reduction among nursing students in southwest Nigeria", concluded that the level of knowledge of nurse students is good about the spread of HI /AIDS, but provides a negative discriminatory attitude towards ODHA.

\section{Effect of knowledge on stigma}

Based on the results of the study indicate that knowledge affects stigma. Knowledge that consists of the causes, spreads and impacts that are dominated by the 


\section{STRADA Jurnal Ilmiah Kesehatan}

DOI: $10.30994 /$ sjik.v9i2.486

ISSN: 2252-3847 (print); 2614-350X (online)

Vol.9 No.2 November 2020 Page.1457-1462

spread reflected by the COVID-19 virus is spread through droplets (respiratory droplets) from people who have been infected and the COVID-19 virus spreads because interacting with many people influences the stigma of ODP, PDP, Patients and medical personnel, who are dominated by PDP reflected in PDP COVID 19 who are being quarantined independently may not live in the community and PDP COVID 19 who are being quarantined independently should be separated from the surrounding environment because they can transmit the disease. This study is not in accordance with the research conducted by Winnie in 2006 which examined the comparison of Hong Kong people's stigma against patients with HIV/AIDS, SARS, and Tuberculosis. The results of the study are that knowledge does not significantly influence stigma. But what attract the highest stigma of the 3 diseases are HIV/AIDS, because public knowledge of the most dangerous impacts is HIV/AIDS. These results are consistent with the results of our study of community knowledge on the impact of Covid 19 disease that can cause death, so the community gives a stigma to ODP, PDP, and Covid 19 patients.

\section{Effect of attitude on stigma}

Based on the results of research show that attitude influences stigma. The attitude which consists of positive and negative which is dominated by negative which is reflected in the feeling of discomfort if a neighbor becomes ODP COVID 19 and feels uncomfortable if a neighbor becomes PDP COVID 19 affects the stigma of ODP, PDP, Patients and medical personnel, which is dominated by PDP that is reflected in COPID 19 PDP that is being quarantined independently may not live in the community and PDP COVID 19 which is being quarantined independently should be separated from the surrounding environment because they can transmit the disease. This is consistent with what was stated in a systematic literature review study by Logie, 2020, in the research title "How Do We Balance Tensions between COVID-19 Public Health Responses and Stigma Mitigation? Learning from HIV Research "that one of anticipating the stigma of Covid 19 is to control attitudes in society, learn from HIV/AIDS cases.

\section{Effect of knowledge on stigma through attitude}

Based on the results of the study indicate that knowledge affects stigma through attitude. Which means that the spread of the COVID-19 virus spreads through the droplets (respiratory droplets) of people who have been infected and also the COVID19 virus can spread because a person interacts with many people so that there arises a negative attitude on discomfort if there are neighbors being ODP COVID 19 and feel uncomfortable if there are neighbors who are PDP COVID 19 that have an impact on PDP COVID 19 who are being quarantined independently may not live in the community and PDP COVID 19 who is being quarantined independently should be separated from the surrounding environment because they can transmit the disease. Which means that attitude can mediate knowledge in increasing stigma. The results of this study are consistent with research conducted by Laura in 2017, in her research on the impact of how knowledge can affect attitude change is important to understand the consequences for stigma in mental illness patients and the result that there is an influence of knowledge on attitudes and can create stigma for patients. 


\section{STRADA Jurnal Ilmiah Kesehatan}

DOI: $10.30994 /$ sjik.v9i2.486

ISSN: 2252-3847 (print); 2614-350X (online)

Vol.9 No.2 November 2020 Page.1457-1462

\section{CONCLUSIONS}

Public knowledge of the causes, spreads and effects of influence influenced community attitudes so that negative attitudes arise in the ODP, PDP, Covid 19 Patients and health workers.

Public knowledge of the causes, spread and impact of negative stigma affects the ODP, PDP, Covid 19 Patients and health workers.

The negative attitude of the community towards ODP, PDP of Covid 19 patients and health workers who are suspected of being infected has an influence on the negative community stigma of ODP, PDP of Covid 19 patients and health workers.

Public knowledge of the causes, spread and impact of negative stigma effects on ODP, PDP 19 patients and health workers through negative attitudes, such as feeling uncomfortable living around ODP, PDP, Covid 19 patients and health workers.

\section{REFERENCES}

Adekunbi A Farotimi, Chinomso Ugochukwu Nwozichi, 2015. Knowledge, attitude, and practice of HIV/AIDS-related stigma and discrimination reduction among nursing students in southwest Nigeria. Iranian journal Of Nursing And Midwifery Research. https://dx.doi.org/10.4103\%2F1735-9066.170011

Bruce G, 2012. Labeling and Stigma. Handbook of the Sociology of Mental Health pp 525-541. https://link.springer.com/chapter/10.1007/978-94-007-4276-5_25

Eagly, A.H. and Chaiken, S. (1993). The Psychology of Attitudes. Fort Worth: Harcourt Brace Jovanovich College Publishers.

Fitriani S. Promosi Kesehatan Yogyakarta: Graha ilmu; 2011.

Goffman, 1959 the presentation of self in everyday life. Garden City, N. Y. : doubleday

Logie CH, Turan JM, 2020. How Do We Balance Tensions Between COVID-19 Public Health Responses and Stigma Mitigation? Learning from HIV Research. Europe PMC. https://doi.org/10.1007/s10461-020-02856-8

Laura Simmons, Tim Jones, Eleanor Bradley, 2017. Reducing Mental Health Stigma. European Journal of Mental Health

Notoatmodjo S. Ilmu prilaku kesehatan Jakarta: Rineka Cipta; 2010.

Laura H. Thompson, Elsabé du Plessis,Lisa Lazarus,Sushena Reza-Paul,Syed Hafeez Ur Rahman, 2013. Beyond internalised stigma: daily moralities and subjectivity among self-identified kothis in Karnataka, South India. International Journal for Research, Intervention and Care. https://www.tandfonline.com/doi/abs/10.1080/13691058.2013.818714

World Health Organization (2020). Coronavirus.

Winnie W.S.MakPhoenix K.H.et all. 2006. Comparative stigma of HIV/AIDS, SARS, and Tuberculosis in Hong Kong. Social Science \& Medicine Elsevier journal. https://doi.org/10.1016/j.socscimed.2006.04.016 